\title{
Short-term effects of fire on plant cover and soil conditions in two Austrocedrus chilensis (cypress) forests in Patagonia, Argentina
}

\author{
M. Florencia URRETAVIZCAYA ${ }^{\mathrm{a}, \mathrm{b} *}$, Guillermo E. Defosséa, ${ }^{\mathrm{a}}$, Héctor E. GONDA ${ }^{\mathrm{a}}$ \\ ${ }^{a}$ Centro de Investigación y Extensión Forestal Andino Patagónico (CIEFAP) and Universidad Nacional de la Patagonia, \\ Ruta 259, km 4, (9200) Esquel, Chubut, Argentina \\ ${ }^{\mathrm{b}}$ Consejo Nacional de Investigaciones Científicas y Técnicas de Argentina (CONICET), Argentina
}

(Received 4 October 2004; accepted 5 July 2005)

\begin{abstract}
Early post-fire effects on plant cover, in soil temperature $(0,5,20$, and $30 \mathrm{~cm}$ depth) and moisture $(0-16,20-36$, and $40-56 \mathrm{~cm}$ depth) were analyzed for two years in two cypress stands in Patagonia, Argentina. Each stand (Trevelin = xeric and Bolsón $=$ mesic $)$ contained three treatments: unburned (UN), partially (PB), and completely burned (CB). In Trevelin, 4 and 6 years after fire, understory cover increased $(\mathrm{CB}>\mathrm{PB}>\mathrm{UN})$ and overstory decreased $(\mathrm{CB}=\mathrm{PB}<\mathrm{UN})$ related to the burning treatment. In Bolsón, one year after fire, all treatments had similar under- and overstory cover, but were similar to Trevelin two years later. Soil temperature was significantly different (PB $>C B>$ UN) at all depths and dates only in Trevelin. Soil moisture was significantly higher in the burned treatments of both stands. While plant cover might have protective effects and soil water appears as not limiting, high soil temperatures seem to be detrimental for post-fire cypress establishment, especially in xeric sites.
\end{abstract}

Austrocedrus / fire / soil temperature-moisture / southern temperate forest / establishment

Résumé - Les effets du feu à court terme sur la couverture végétale et sur les conditions du sol dans deux forêts d'Austrocedrus chilensis (cyprès) en Patagonie, Argentine. On analyse ici les effets du feu à court terme sur la couverture végétale, la température $(0,5,20$, et $30 \mathrm{~cm}$ de profondeur) et l'humidité du sol (0-16, 20-36, et 40-56 cm de profondeur) dans deux peuplements de cyprès en Patagonie, Argentine, au long de deux années. Les peuplements $($ Trevelin = xérique; Bolsón = méssique) présentent trois traitements : non-brûlé $(\mathrm{UN})$, partiellement brûlé $(\mathrm{PB})$ et totalement brûlé $(\mathrm{CB})$. À Trevelin, 4 et 6 ans après le feu, la couverture du sous-bois inférieur augmenta $(\mathrm{CB}>\mathrm{PB}>\mathrm{UN})$ tandis que celle du sous-bois supérieur diminua $(\mathrm{CB}=\mathrm{PB}<\mathrm{UN})$ dépendant du traitement de brûlage. À Bolsón, un an après le feu, la couverture des deux étages du sous-bois fut la même pour les trois traitements, quoique deux ans plus tard la situation se rapprocha de celle de Trevelin. Seule à cet endroit, la température du sol montra des différences significatives $(\mathrm{PB}>\mathrm{CB}>\mathrm{UN})$ à chaque profondeur et à chaque date. Dans les deux peuplements, l'humidité du sol a été nettement plus haute pour les traitements brûlés. Tandis que la couverture végétale pourrait avoir des effets de protection et que l'humidité du sol n'apparaît pas comme étant limitative, les hautes températures du sol semblent être restrictives pour l'établissement des cyprès à la suite du feu, notamment dans les sites xériques.

Austrocedrus / feu / température / humidité du sol / forets tempérées / établissement

\section{INTRODUCTION}

One of the main effects of fire on forest communities is the opening of gaps of various sizes in which the normal radiation regime is altered, producing substantial differences in microclimate between newly burned and unburned canopy-covered areas [7]. In burned areas, soil surface is affected by both, the immediate and direct effect of heat caused by the actual fire, and by the additional and long-lasting effects of absorbed radiation received by the blackened surface after the fire has passed. Apart from the damage caused to aboveground biomass, fire can alter same properties of the soil, mainly due to the rapid combustion of the organic matter located on its surface $[1,11]$. If the organic horizon is consumed, the exposed mineral soil may increase its temperature for months, or even years, due to the direct radiation received $[33,35]$. The subsequent changes in soil temperature and other soil properties caused by fire will certainly influence post-fire community succession, and may affect nutrient cycling, water relations, microbial community structure, and seedling establishment $[11,12,35]$.

In northwestern Patagonia the Austrocedrus chilensis (D. Don) Pic. Ser. et Bizzarri forests (locally called cypress) occupy 140000 ha. Stands occur along a narrow strip between $37^{\circ} 08^{\prime} 09^{\prime \prime}$ and $43^{\circ} 43^{\prime} 57^{\prime \prime} \mathrm{S}$ and $71^{\circ} 49^{\prime} 18^{\prime \prime}$ and 70 $30^{\prime} 29^{\prime \prime} \mathrm{W}$ [6]. This $50 \mathrm{~km}$ wide strip of forest comprises one of the most extreme west-east precipitation gradients in the world [50]. Cypress is a long-lived species [29] and forms dense, mixed stands with Nothofagus dombeyi (Mirb.) Oerst. (locally called

* Corresponding author: urretaf@ ciefap.org.ar 
coihue) in humid sites, pure stands on drier sites, and open stands on xeric sites near the ecotone between the forest and the Patagonian steppe. Fire is the main disturbance associated to the dynamics of cypress forests [49].

In these forests, the natural fire regime varies according to the precipitation regime. In general, fire frequency increases from the humid sites in the west, towards the xeric sites in the east [22]. In the past, fire frequency increased in the majority of cypress stands after 1850 , coincidentally with an increase in number of indigenous people that inhabited the region and the beginning of European settlement. This frequency peaked at the end of the XIXth century, and started to decline from then on because indigenous population decreased, and the creation of several National Parks in the region brought about the policy of fire suppression [48].

Intense fires produce severe cypress damage and mortality, since this species has a very thin bark and is unable to sprout [49]. After a fire event, however, cypress establishment seems to be influenced by site conditions, being rapid in humid and mesic sites and slower in xeric areas [24, 49]. Since this species reproduces almost exclusively by seed, regeneration is conditioned by the chance of seeds to find "safe sites" (sensu Harper [18]) where they can successfully germinate and become established. This series of events depends on the availability of germinable seeds, restrained by the distance to the mother tree because of its low dispersal capacity [14, 49], and a transient seed bank [47], the occurrence of favorable weather periods [51], and the presence of a propitious soil microsite. In unburned vegetation, the protection provided by understory vegetation seems to benefit cypress stand recruitment [16, 44].

During the last decade, fires affected 77000 ha of native forests in the Provinces of Río Negro and Chubut [38, 46]. Within these provinces, cypress forest were the most affected after Nothofagus antarctica (Forst. F.) Oerst. (locally called ñire) forests. In general, fires are of anthropogenic origin (accidental and/or intentional), being less frequent those produced by natural causes [13]. The possibility of occurrence of big, intense fires has increased because the reduction in fire frequency caused by the suppression policy implemented in the XXth century allowed the accumulation and continuity of fine fuels [23].

Some studies have dealt with the dynamics of cypress stands at different time-span periods after fire events [15, 17, 22, 51]. However, little emphasis has been placed on the importance that microenvironmental and biotic conditions achieved in the first successional stages after the fire, especially plant cover and soil temperature and soil moisture, may play in seedling dynamics. The occurrence of dry periods, high temperatures and scarce water availability during the growing seasons are known as limiting factors for the establishment, survival and growth of several forest species [26] similar to what might happen with cypress. The objectives of this study were to characterize: (a) the temporal changes in plant cover in cypress stands completely burned, partially burned and unaffected by fire (unburned); (b) the seasonal dynamics of temperature and moisture at various soil depths in these burned and adjacent unburned areas, and (c) how changes in plant cover and temperature and moisture in the soil caused by fire may affect cypress seedlings establishment.

\section{MATERIALS AND METHODS}

\subsection{Study area}

A similar study was carried out during the years 2000 to 2002 in two pure cypress stands located $220 \mathrm{~km}$ apart within the southern portion of the distribution area of cypress in Patagonia. The first stand, called Trevelin $\left(43^{\circ} 12^{\prime} 57^{\prime \prime} \mathrm{S}, 71^{\circ} 31^{\prime} 15^{\prime \prime} \mathrm{W}\right)$, located close to the city of Trevelin in Chubut province, had been burnt in December 1996. The second study, referred to as Bolsón, was located in the Loma del Medio-Río Azul Forest Reserve (41 59' 02" S, 71 33' 20" W), in the outskirts of El Bolsón town, in Río Negro province, and had been burnt in January 1999. The unburned portion of the Trevelin stand was 44.2 years old $( \pm 6.7)$ and had 958 cypress ha ${ }^{-1}$, with a dominant height of $13 \mathrm{~m}$, and a quadratic mean diameter (QMD) of $18.7 \mathrm{~cm}$. The unburned fraction of the Bolsón stand was 81.4 years old $( \pm 6.2)$ and had 864 cypress ha $\mathrm{a}^{-1}$, with a dominant height of $18 \mathrm{~m}$, and had a QMD of $20.7 \mathrm{~cm}$. Soil parent material was volcanic ash on both study sites [8, 9]. While the Trevelin stand presented a glacifluvial lithological discontinuity [28] and an A horizon with silty-clay texture, the Bolsón stand showed a very deep soil and an A horizon with loamy texture.

The climate in both study sites is temperate, with $75 \%$ of the annual precipitation falling between April and September (late fall and winter in the Southern Hemisphere). Spring and summer are generally warm and dry [10]. Mean annual temperature and precipitation are $8.2{ }^{\circ} \mathrm{C}$ and $684 \mathrm{~mm}$ in Trevelin [3] and $9.9^{\circ} \mathrm{C}$ and $921 \mathrm{~mm}$ in Bolsón [7]. Trevelin could be considered a xeric site while Bolsón would be mesic. Precipitation fallen during the first growing season considered in this study (2000-2001) was $187 \%$ and $156 \%$ higher than mean climatic values registered for Trevelin and Bolsón, respectively, while for the second growing season (2001-2002), by contrast, these values diminished to $49 \%$ and $60 \%$ for each site, respectively. Taking these values into consideration and according to other authors $[24,31]$, the first growing season was considered in this study as humid, while the second as very dry.

\subsection{Stands selection and sampling procedure}

Within each stand, an area was identified in a way that, containing the fire line, presented similar characteristics related to local conditions such as slope and exposure as well as similarities in stand structure before the fire took place. The size of the study area was $144 \mathrm{~m}$ by $44 \mathrm{~m}$ in Trevelin stand and $128 \mathrm{~m}$ by $64 \mathrm{~m}$ in Bolsón stand. Each study area included three contiguous but different levels of fire disturbance: Unburned (UN): a sampling area upon which no cypress trees or its understory had been affected by the fire; Partially Burned (PB): sampling area had been affected by fire, burning its understory and overstory, but contained living cypress trees; and Completely Burned (CB): in which the understory and overstory of the sampling area had been affected by fire, and presented no surviving cypress trees around them. Each level of fire disturbance was considered to be the treatments in each study. The Trevelin study area was fenced to prevent grazing by large herbivores (mainly cattle) but this was not necessary at the Bolsón study area. Fifteen $40 \mathrm{~m}^{2}$ circular plots were randomly established within each study area. These plots were the sampling units in which the different response variables were measured. Since the resulting number of plots per treatment was uneven, we used an unbalanced experimental design.

\subsection{Plant cover}

Understory and overstory cover was assessed separately by subsampling each sampling unit. In the case of understory cover, five circular subplots $2.4 \mathrm{~m}$ in diameter were established in each sampling unit. One subplot was located at the center of the sampling unit, while 
the other four were equidistant from one another. Understory cover was determined by visually estimating the percentage of soil surface covered by plants in each subplot, dividing it into four quadrants to simplify the procedure. A mean value per sampling unit was obtained.

In each sampling unit, overstory cover was determined in the center of the five subplots established to measure understory cover. Overstory cover was measured at $1.30 \mathrm{~m}$ aboveground with a Spherical Densiometer Model A. At each point, four readings were recorded, each one facing to a cardinal point, according to the technique proposed by Lemmon [30]. This cover, thus, included live and dead trees as well as shrubs at least $1.5 \mathrm{~m}$ tall.

At the beginning of the study, cypress regeneration was determined by counting the seedlings of this species that were smaller than $5 \mathrm{~cm}$ of diameter at breast height (DBH). Four categories were differentiated in relation to the size of regeneration. Plants whose height was below $20 \mathrm{~cm}$ were considered as belonging to category 0 ; those from 20 to $50 \mathrm{~cm}$ in height to category I; from 50 to $130 \mathrm{~cm}$ in height to category II; and those whose height was above $130 \mathrm{~cm}$ but their DBH was below $5 \mathrm{~cm}$, to category III. Cypress seedlings belonging to category 0 were counted in $18 \mathrm{~m}^{2}$ concentric plots within each $40 \mathrm{~m}^{2}$ plots on which the other categories were counted.

\subsection{Soil temperature and moisture}

Soil temperature was measured at four different depths on several points (subsamples) within each sampling unit. Soil temperature at depths 0 and $5 \mathrm{~cm}$ (ST-0 and ST-5) was measured on five points in each sampling unit, on the same points where overstory cover was determined. Temperature at depths 20 and $30 \mathrm{~cm}$ (ST-20 and ST-30) was measured only in two points, randomly selected among those five due to smaller variation associated with soil depth. Temperature at all depths was measured from September 2000 to April 2002, every 20 days during spring and summer and every three months during fall and winter. Temperature at the soil surface was measured between 14:00 and 14:30 h, and ST-5, ST-20, and ST-30 between 14:00 and 17:00 h. Surface temperature was measured with a laser thermometer (Cole Parmer SM 39650-02), and ST-5, ST-20 and ST-30 with thermocouple thermometers (Cole Parmer Digi-Sense Model NO 91100-50).

Soil moisture of three different soil layers, 0 to $16 \mathrm{~cm}$ (SM-0), 20 to $36 \mathrm{~cm}$ (SM-20), and 40 to $56 \mathrm{~cm}$ (SM-40), was measured at several points (sub-samples) within each sampling unit. SM-0 was measured on five points in each sampling unit in the same points where ST-0 and ST-5 were determined; SM-20 and SM-40 were measured in one point on the edge of the sampling unit. From September 2000 to April 2002 SM-0 was measured at the same time intervals as temperatures. Soil moisture in the other two layers (SM-20 and SM-40) was measured in April and October 2001, and in January and April 2002, each time in a different location along the edge of the sample unit. SM-0 was determined between 10:00 and 12:00 $\mathrm{h}$ and in SM-20 and SM-40 between 14:00 and 17:00 h. Soil moisture was measured with a TDR IMKO Trime FM-3 hand-held moisture meter with P3 sensors $16 \mathrm{~cm}$ long.

\subsection{Design and analyses}

On both study sites, the effects of the treatments on understory and overstory were analyzed separately for each year with ANOVA techniques. The same technique was used to analyze cypress regeneration. Multiple comparison of means to test significant differences among treatments were analyzed with Tukey-Kramer test. This test is a modification of Tukey test for unbalanced designs [45]. The effects of the treatments on temperature and moisture at different soil depths through time were analyzed with repeated measures analysis of variance [53] because measurements were taken on the same experimental unit. In this case where the tests involve only between-subjects effects, both multivariate and univariate approaches give rise to the same test [45]. The Tukey-Kramer test was used to determine significant differences among these variables.

\section{RESULTS}

\subsection{Plant cover}

In Trevelin, the effects of the fire treatments on plant cover showed a similar pattern four (2000) and six (2002) years after fire (Figs. 1a and 1b). Understory cover increased in direct relation to the degree of burning $(\mathrm{CB}>\mathrm{PB}>\mathrm{UN})$, and the differences among treatments were significant $(p<0.01)$. The percentage of cover was about $80 \%, 40 \%$ and $10 \%$ in CB, PB, and UN treatments, respectively, for both years (Fig. 1a). Overstory cover, by contrast, showed an inverse pattern (UN $>$ PB $>$ $\mathrm{CB})$, being significantly higher $(p<0.01)$ in the UN $(60 \%)$ as compared to PB (25\%) and CB (20\%) (Fig. 1b). The presence of cypress regeneration of all sizes was absent in $\mathrm{CB}$, and in all but in Category II in PB. All these values were significantly lower $(p<0.05)$ with respect to UN (Tab. I). No further seedling establishment was observed during the rest of the study period.

In Bolsón, results in the year 2000 were different from those obtained in the year 2002. In 2000, both covers (Figs. 1c and 1d) were not significantly different in all plots regardless the degree of burning. By contrast, in 2002, understory cover increased $(p<0.01)$ in direct relation to the degree of burning $(\mathrm{CB}>\mathrm{PB}>\mathrm{UN})$, while overstory cover decreased $(p<0.01)$ in the $\mathrm{PB}$ and $\mathrm{CB}$ treatments related to UN. In this site, cypress regeneration was absent for $\mathrm{CB}$, while it took intermediate values for PB as compared to CB and UN (Tab. I). The individuals counted in $\mathrm{PB}$ are those which survived the fire event.

\subsection{Soil temperature}

In Trevelin, soil temperature in the $\mathrm{PB}$ and $\mathrm{CB}$ treatments was significantly higher $(p<0.01)$ than in UN at all soil depths and during the whole study period (Figs. $2 \mathrm{a}$ to $2 \mathrm{~d}$ ), these differences being of higher magnitude during the growing season. In these seasons, in PB treatment, ST- 0 and ST-5 reached $57^{\circ} \mathrm{C}$ and $31^{\circ} \mathrm{C}$, respectively. In the $\mathrm{CB}$ treatment, ST-0 and ST-5 reached $49^{\circ} \mathrm{C}$ and $29^{\circ} \mathrm{C}$, while in UN, never exceeded $42^{\circ} \mathrm{C}$ and $22^{\circ} \mathrm{C}$, respectively. In Trevelin, ST-0 recorded in the UN treatment exceeded $40^{\circ} \mathrm{C}$ only once during the first summer, while in PB and CB, ST-0 remained above $40{ }^{\circ} \mathrm{C}$ for three and two months, respectively (Fig. 2a). Below soil surface, ST-5 went above $20^{\circ} \mathrm{C}$ only once (in February of 2002) for the UN, while for PB and CB these temperatures remained above $20^{\circ} \mathrm{C}$ for about five months for the first year and for four months for the second year, respectively. Deeper into the soil, the pattern of ST-20 and ST-30 was similar to that described for ST-0 and ST-5, although temperatures were of lower values.

In Bolsón, by contrast, soil temperature during the study period was similar in the three treatments at all depths (Figs. $2 \mathrm{e}$ to $2 \mathrm{~h}$ ). One year after the fire event, ST-0 reached $37^{\circ} \mathrm{C}$ and $42{ }^{\circ} \mathrm{C}$ in the $\mathrm{PB}$ and $\mathrm{CB}$ treatments, and $44^{\circ} \mathrm{C}$ in the UN. On the second growing season, ST-0 never exceeded $39^{\circ} \mathrm{C}$ in the 
Trevelin
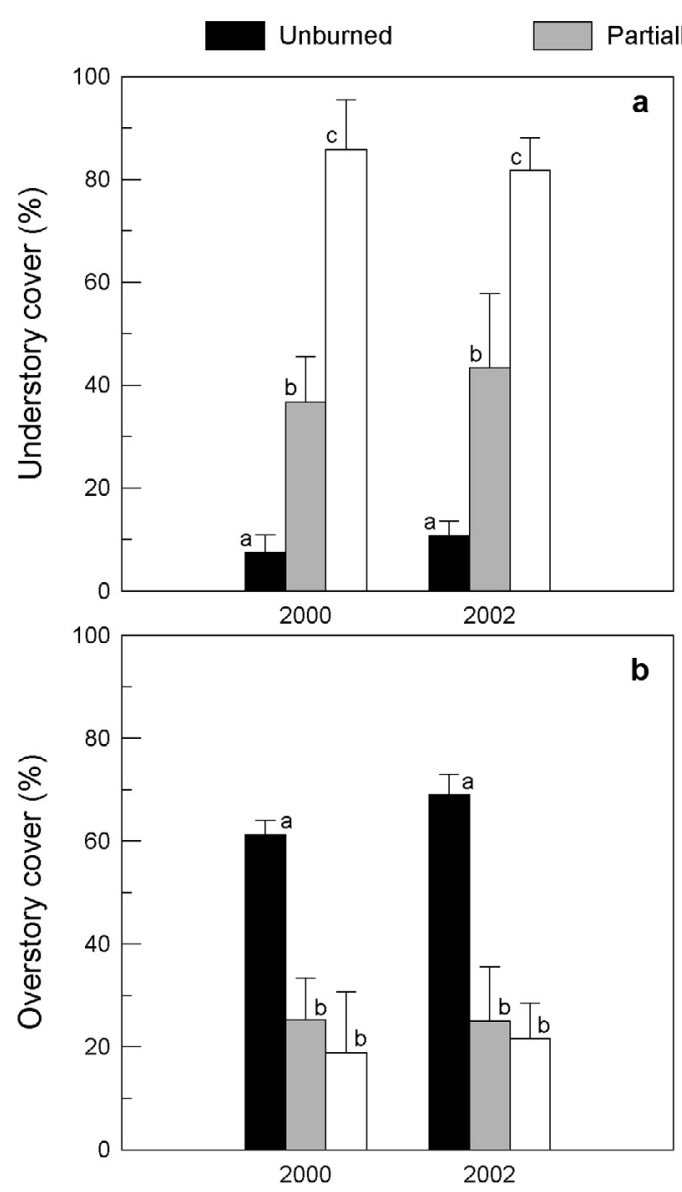

Bolsón

Completely Burned
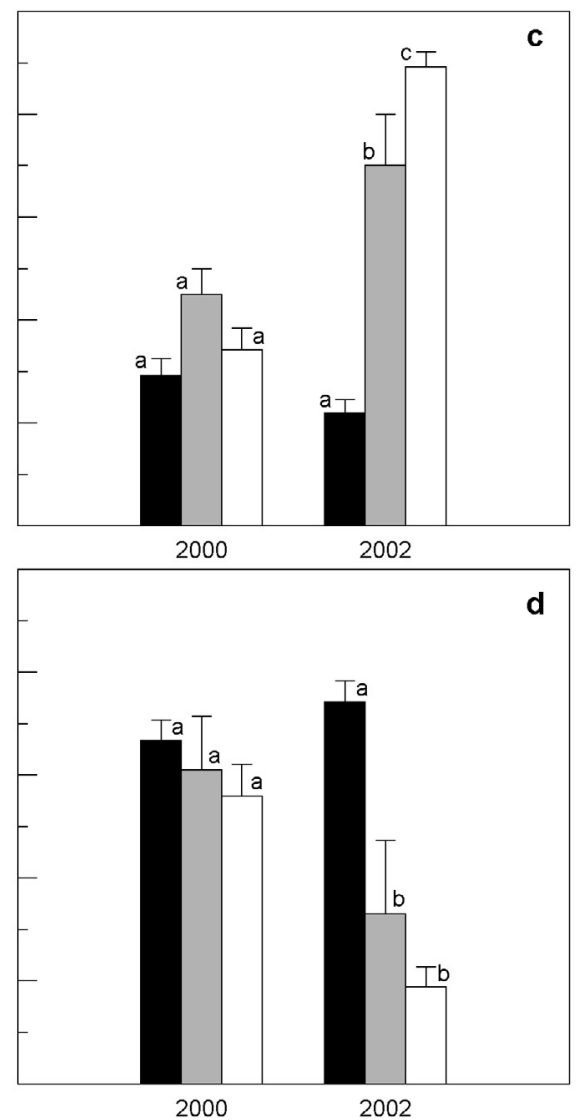

Figure 1. Mean percentage ( \pm one standard error) of understory $(\mathbf{a}, \mathbf{c})$ and overstory cover $(\mathbf{b}, \mathbf{d})$ for Trevelin and Bolsón, measured in 2000 and 2002. Lower case letters above bars indicate significant differences at $(p<0.05)$ among treatments.

Table I. Cypress regeneration, expressed as individuals ha ${ }^{-1}$ ( \pm one standard error) per treatment in both study areas. Treatments showing different letters indicate significant differences at $p<0.05$ for every category and within each study area.

\begin{tabular}{|c|c|c|c|c|c|c|}
\hline \multirow[b]{2}{*}{ Regeneration } & \multicolumn{3}{|c|}{ Trevelin } & \multicolumn{3}{|c|}{ Bolsón } \\
\hline & UN & $\mathrm{PB}$ & $\mathrm{CB}$ & UN & $\mathrm{PB}$ & $\mathrm{CB}$ \\
\hline Cat. 0: $<20 \mathrm{~cm}$ height & $\begin{array}{l}1759.2 \mathbf{a} \\
( \pm 804.0)\end{array}$ & $0 \mathbf{b}$ & $0 \mathbf{b}$ & $\begin{array}{c}56983.6 \mathbf{a} \\
( \pm 21333.3)\end{array}$ & $\begin{array}{l}3888.8 \text { ab } \\
( \pm 3333.3)\end{array}$ & $0 \mathbf{b}$ \\
\hline Cat. I: $>20 \mathrm{~cm}$ and $\quad<50 \mathrm{~cm}$ height & $\begin{array}{c}3291.6 \mathbf{a} \\
( \pm 2293.4)\end{array}$ & $0 \mathbf{b}$ & $0 \mathbf{b}$ & $\begin{array}{l}1.0417 \mathbf{a} \\
( \pm 553.1)\end{array}$ & $\begin{array}{c}125.0 \mathbf{a b} \\
( \pm 125.0)\end{array}$ & $0 \mathbf{b}$ \\
\hline Cat. II: $>50 \mathrm{~cm}$ and $<130 \mathrm{~cm}$ height & $\begin{array}{c}2666.6 \mathbf{a} \\
( \pm 1333.3)\end{array}$ & $\begin{array}{c}83.3 \mathbf{b} \\
( \pm 83.3)\end{array}$ & $0 \mathbf{b}$ & $\begin{array}{c}666.7 \mathbf{a} \\
( \pm 368.9)\end{array}$ & $0 \mathbf{b}$ & $0 \mathbf{b}$ \\
\hline Cat. III: $>130 \mathrm{~cm}$ height and $<$ a $5 \mathrm{~cm} \mathrm{DBH}$ & $\begin{array}{l}2791.6 \mathbf{a} \\
( \pm 820.1)\end{array}$ & $0 \mathbf{b}$ & $0 \mathbf{b}$ & $\begin{array}{l}978.3 \mathbf{a} \\
( \pm 430.2)\end{array}$ & $\begin{array}{c}250.0 \mathbf{a b} \\
( \pm 250.0)\end{array}$ & $0 \mathbf{b}$ \\
\hline
\end{tabular}

UN, but reached peaks of $55^{\circ} \mathrm{C}$ and $40^{\circ} \mathrm{C}$ on $\mathrm{PB}$ and $\mathrm{CB}$, respectively. Although ST-5 showed no significant differences among treatments during the whole study period, it did show significant differences $(p \leq 0.01)$ between CB and UN during the spring of the first growing season (2000, Fig. 2f). These differences, of about $4{ }^{\circ} \mathrm{C}$, occurred concomitantly with the higher ST-0 registered the first growing season after the fire event (2000-2001). 
Trevelin
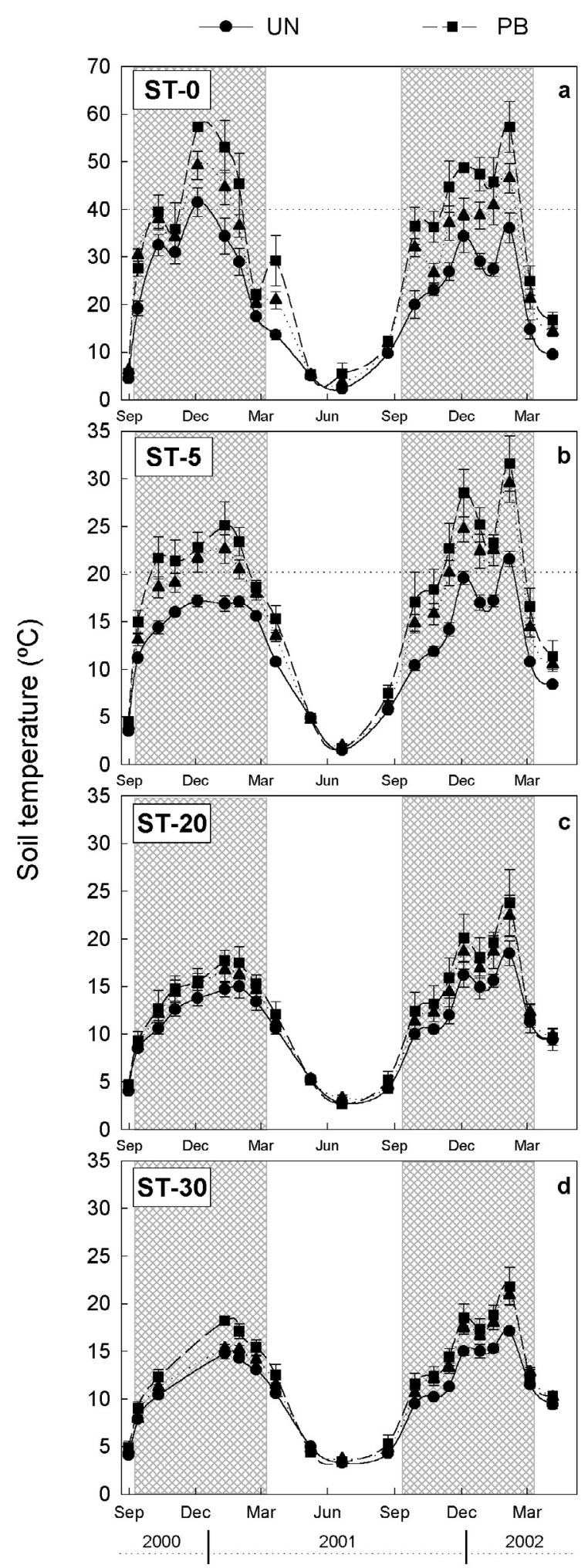

Bolsón

$\cdots$. $\cdots \mathrm{CB}$

GS
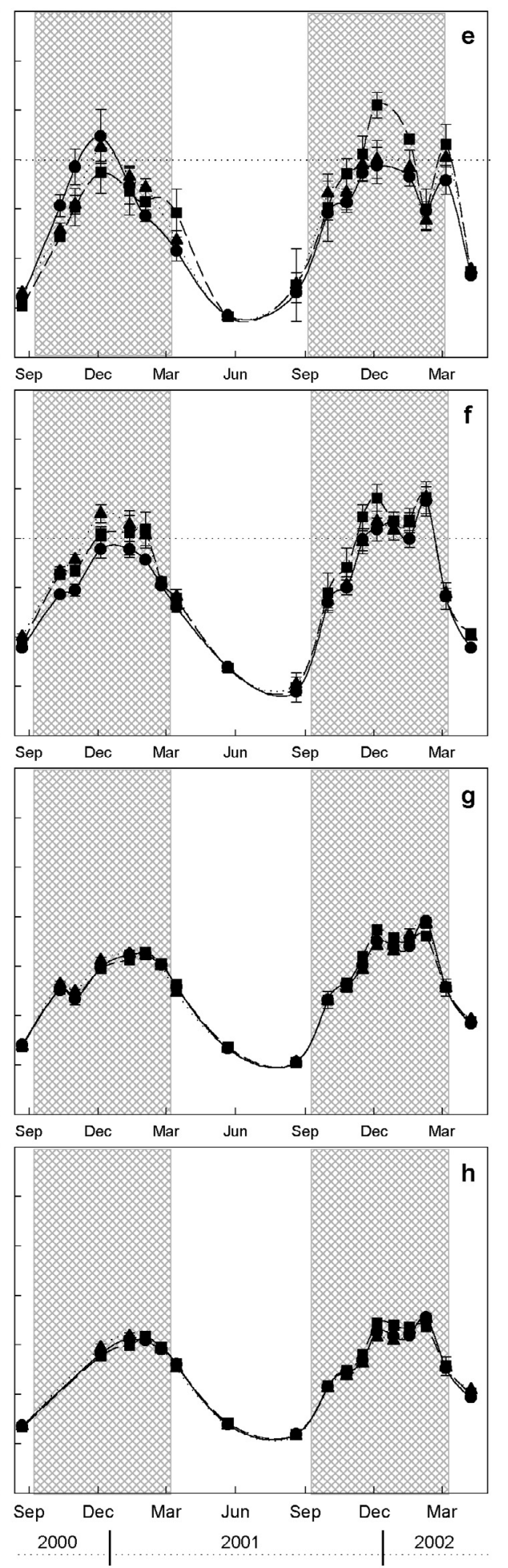

Figure 2. Soil temperature (average \pm one standard error) at different depths measured during September 2000 and April 2002 in Trevelin and Bolsón, respectively. ST-0, ST-5, ST-20, and ST-30, represent soil temperatures at 0, 5, 20 and $30 \mathrm{~cm}$ in depth respectively. Shaded areas represent the growing seasons. 


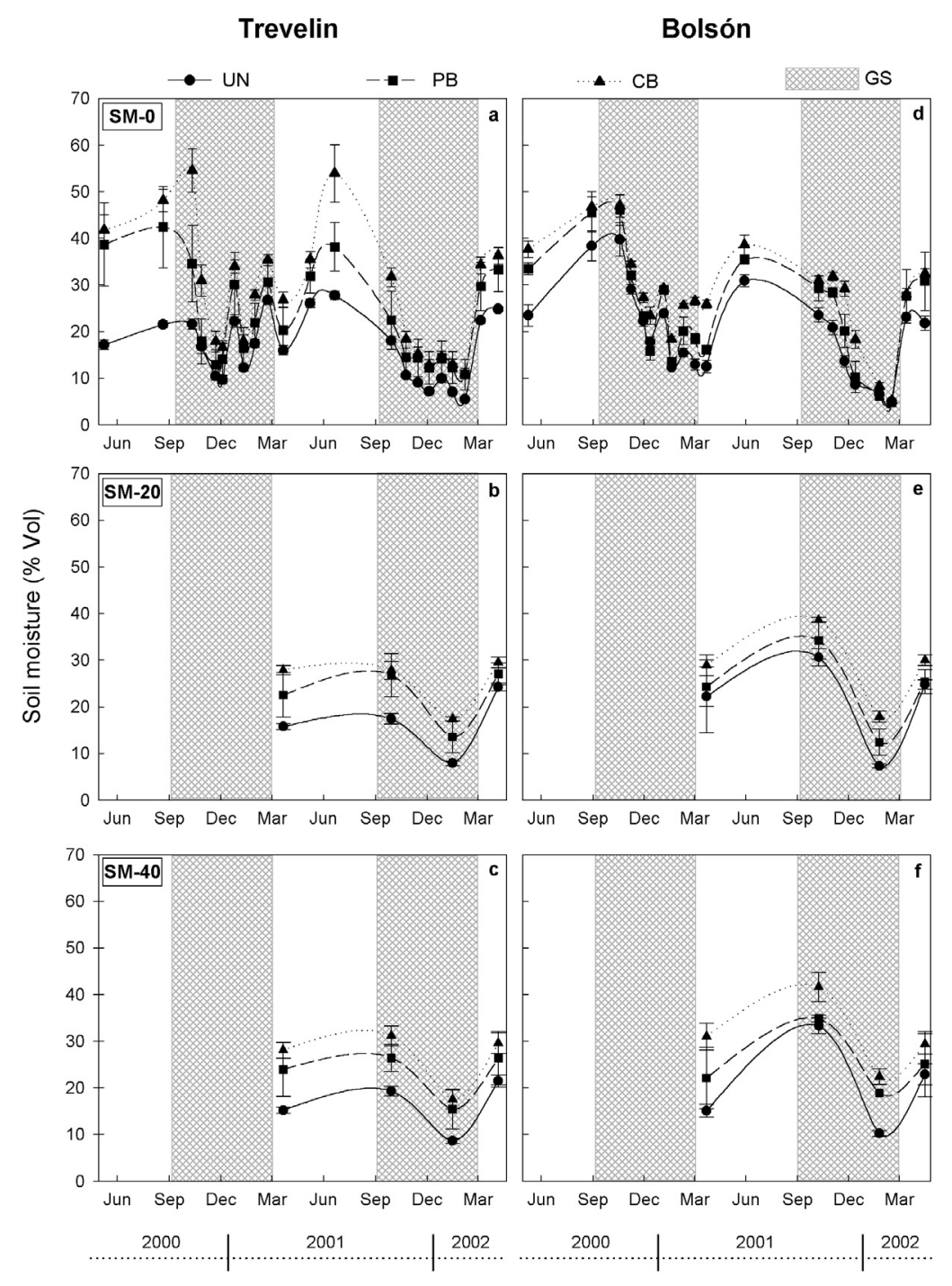

Figure 3. Soil moisture (average \pm one standard error) at different depths measured during September 2000 and April 2002 in Trevelin and Bolsón, respectively. SM-0, SM-20, y SM-40 represent soil moisture between 0 and $16 \mathrm{~cm}, 20$ and $36 \mathrm{~cm}$, and 40 and $56 \mathrm{~cm}$ in depth respectively. Shaded areas represent the growing seasons.

\subsection{Soil moisture}

In Trevelin, soil moisture showed significantly higher differences $(p \leq 0.01)$ among depths and treatments. Considering the whole study period, SM-0 and SM-20 were higher on PB and $C B$ in relation to $\mathrm{UN}$, while SM-40 was higher only in CB (Figs. 3a to 3c). Although the pattern of variation in SM-0 was similar for all three treatments, the range of values was different. For example in CB treatment, SM-0 reached values higher than $50 \%$ during spring of the first growing season and up to the following winter, descending to $11 \%$ during the next season (very dry). In the UN, by contrast, SM-0 never exceeded $28 \%$, descending to $5 \%$ during the very dry season. Absolute differences in SM-0 between CB and UN were always higher than 4\% (Fig. 3a). In all three treatments, SM-20 and SM-40 also showed a similar pattern of variation. At these two depths, soil moisture in CB varied between $17 \%$ and $32 \%$, while in UN var- ied between $8 \%$ and $24 \%$. The CB treatment always showed soil moisture content that was, in average, $9 \%$ higher as compared to UN, except in April 2002, when it was only 6\% higher.

In Bolsón and during the whole study period, SM-0 and SM20 were significantly higher $(p<0.05)$ in treatments $\mathrm{CB}$ and $\mathrm{PB}$ as compared to UN, while SM-40 was significantly higher $(p<0.05)$ in $\mathrm{CB}$ as compared to UN (Figs. $3 \mathrm{~d}$ to $3 \mathrm{~g}$ ). In this site, maximum values in SM-0 differed among treatments for the first season (46\% in $\mathrm{CB}$ and $\mathrm{PB}, 39 \%$ in UN), while for the second season (very dry) the minimum value was similar for the three treatments (Fig. 3d). The pattern of soil moisture variation was similar at SM-20 and SM-40 for all three treatments but, as reported for Trevelin, CB was the treatment that presented the highest moisture values, and UN, the lowest. Moisture variation ranged from $17 \%$ to $42 \%$ for $\mathrm{CB}$, while it was $7 \%$ to $33 \%$ for UN. 


\section{DISCUSSION}

\subsection{Plant cover}

In Trevelin, understory and overstory cover had not varied too much between the fourth (2000) and the sixth (2002) year after the fire had taken place, because four years after the fire event, most of the remaining snags had already fallen and the herbs had had the chance to spread along the partially and completely burned areas. In Bolsón, by contrast, one year after the fire (2000), burned trees were still standing, and the herbaceous species just started to establish. Similar results were reported for Pinus halepensis Mill. Forests in the Iberian Peninsula, where eight months after the fire, the herbaceous strata did not show any association with the severity classes considered [39]. In Bolsón three years after the fire, understory vegetation had already colonized the burned areas, and plant cover showed a similar pattern as the one observed in Trevelin. Similar pattern of herbage recovery, decrease of bare soil areas and lack of regeneration 15 years after a fire were reported by Gobbi and Sancholuz [17] for another cypress forest. The understory and overstory observed in both sites at the end of the study period does not appear as a limiting factor that would deleteriously affect early cypress seedling establishment. This consideration is based upon the results reported by other studies, which demonstrated the positive relationship that exist among herbaceous and shrub cover and cypress seedling establishment $[16,24,44]$.

\subsection{Soil temperature}

The high soil temperatures recorded for the burning treatments (PB and $\mathrm{CB}$ ) in Trevelin, significantly higher than those of UN treatment, can potentially limit cypress establishment since growth of woody plants seedlings at the cotyledon stage of development are particularity sensitive to temperature extremes [26,27]. The combination of above-normal and long lasting soil and ambient temperatures can cause injury to roots and stems, inhibiting the growth and eventually led to death to seedling shoots $[25-27,55]$.

It has been well established that high temperatures at the soil surface are correlated with low seedling survival in a variety of plant species in many environments [32], including boreal and cold-temperate forests [25]. Optimum soil temperature for root growth of many woody plants of temperate zones is between $20-25^{\circ} \mathrm{C}$ [27]. In Trevelin ST-5 in the UN treatment was always lower than $20^{\circ} \mathrm{C}$, except during the second growing season, when it reached to $22^{\circ} \mathrm{C}$. By contrast, temperatures in $\mathrm{PB}$ and $\mathrm{CB}$ were, in average, $7^{\circ} \mathrm{C}$ higher than in UN during the growing seasons studied. Considering that small deviation in optimum temperatures can affect root growth in several plant species [34], it would be possible that they may affect cypress seedling roots in the same way.

In other temperate forests, when comparing burned with unburned areas, maximum soil temperatures could reach similar values, but in unburned areas these temperatures tend to be of short duration, lasting only for a few days [2]. In the cypress forest stand of Trevelin, the UN treatment registered high temperatures only once, while in burned treatments these high temperatures remained for more than two months in ST-0, and for more than five months in the case of ST-5. Deeper into the soil, although with lower values, the pattern of soil temperature was similar as the one reported for the upper soil. These high temperatures might severely damage cypress seedlings by overheating and dehydration, as has been reported for other species [27]. The rates of extension and root mortality could also be affected if soil temperature reach values that are above the optimum for root growth [40].

In Trevelin, the partially burned areas (PB) showed higher variation in soil temperature as compared to completely burned (CB) areas. This apparently contradictory finding, could be explained by taking into consideration that treatment $\mathrm{CB}$ showed a understory cover more evenly distributed than $\mathrm{PB}$, acting this vegetation a barrier that impeded the direct radiation to reach the ground as may have happened in other sites [27, 54]. Another aspect associated to changes in soil temperature found in these two treatments could be related to the settlement of the treatments themselves. Although the treatments were carefully set, it was unavoidable that small local variations present prior to the fire could have altered (increasing or decreasing), the subsequent effects of fire [5]. The classification of the severity of a fire based only on function of the remaining surviving trees could be then insufficient to classify that event with certain degree of accuracy ([39] and references herein). As pointed out by Robberecht et al. [43] and Robberecht and Defossé [42], more quantitative data about the actual fire and its effects should be necessary to characterize a fire event and its severity. In Trevelin, our PB treatment, then, should be considered only as a relative measure of fire intensity and severity in between the $\mathrm{UN}$ and $\mathrm{CB}$ treatments.

As mentioned above, soil temperature is generally altered after a forest fire, particularly at the soil surface [1]. In Bolsón, however, we found no significant differences in soil temperatures among treatments. Apart from the fact that Bolsón was considered as a mesic site, as compared to Trevelin (xeric), the lack of differences found in soil temperatures among treatments could have been due, in part, to the weather conditions prevailing during the first summer after the fire, which were wetter and cooler than normal. It is well known that due to the latent heat of water, more energy is needed to increase the temperature of a wet soil than one similar that remain dry $[21,34,41]$. In Bolsón, both fire disturbed treatments (PB and $\mathrm{CB}$ ) had higher soil moisture from mid-spring to end of summer than that of the UN treatment (see Fig. 3), and this may have lessened differences in temperature. During the second growing season, although the weather conditions were relatively hot and dry as compared to the long-term mean, the understory cover, by then fully recovered, could have acted as a barrier, in a similar way as it was reported for Trevelin and for other ecosystems [27, 54].

Similarly to what was observed in Trevelin and Bolsón, soils in burned areas of mixed oak forests in Ohio, USA, were warmer than those of the nearby unburned forest, and within them, xeric areas were warmer as compared to mesic. Soils in burned xeric sites showed from $3.5^{\circ} \mathrm{C}$ to $5.7^{\circ} \mathrm{C}$ higher than unburned soils, while these differences were of $0.5^{\circ} \mathrm{C}$ to $0.6^{\circ} \mathrm{C}$ for mesic sites [19]. This pattern was attributed, in part, to the combined effects of higher water content and its thermodynamics and the reduced exposure to direct solar radiation of soils of mesic areas as compared to those of xeric areas [20]. 


\subsection{Soil moisture}

Fire effects upon soil moisture are indirect and not frequently well defined [41], since they depend on different factors such as the amount of Organic Matter consumed [52], soil drainage characteristics [36] and the temperatures reached by the soil at the time of fire and after it [56]. In Trevelin, burned treatments (PB and $\mathrm{CB}$ ) showed higher soil water content at all depths as compared to the unburned treatment (UN) during the whole study period. This condition was independent from the growing season considered, since the first growing season was markedly moist and the second very dry. In Bolsón, the pattern of soil moisture was similar to that of Trevelin, and burned treatments (PB and $\mathrm{CB}$ ) showed higher soil water content at all depths and seasons, the exception being surface soil moisture at the end of the dry season, which was similar for all treatments considered. Soil moisture condition found in burned areas in both study sites, does not appear to be a limiting factor for cypress establishment, since it never was lower than that of unburned areas. The increase in soil moisture content in burned areas as compared to unburned is consistent with the reduction in the amount of vegetation, which may result in lower evapotranspiration rates and low precipitation interception, similar to what Kimmins [21] and O'Neill et al. [36] reported.

\subsection{Conditions for cypress establishment in burned areas}

In the relatively short time after a fire (from one to six years) there are significant changes in understory and overstory, and in the patterns of soil temperature and moisture in burned cypress forests of Patagonia. Once fire disturbance occurs, the duration and magnitude of post-fire changes for stand recovery seemed to be directly related to the environmental conditions prevailing at the time of the fire, after it, and to the specific conditions of the site considered. In burned areas, the consumption of biomass and reduction of vegetation cover by the actual fire increased soil temperatures that may persist for several years, being this effect magnified in xeric areas as compared to mesic. Soil moisture, by contrast, appeared as a non limiting factor in either site, since burned plots had always higher water content at all depths than unburned ones.

Burned areas showed also significantly less germinable seeds than unburned areas [47], adding another factor that may reduce the availability of "safe sites" for successful seedling germination and establishment. This synergistic effect (lower seed availability and higher soil temperatures) appear to be magnified in the more xeric site (i.e. Trevelin). In contrast, at Bolsón site (a more humid site and with least extreme soil temperature values), this effect seems to be lessened, particularly in the first few years after the fire. Similar to what happens with cypress, in species such as Picea glauca, regeneration in the first years after the fire would depend on the presence of propagules and of the characteristics of the seed bed [4].

High and persistent soil temperatures in xeric areas may help explain why, apart from the fact that cypress has a transient soil seed bank and that its size is greatly influenced by the degree of fire disturbance [47], burned cypress forests recover faster in mesic or humid areas, as compared to xeric sites. Our results thus coincidence with what was reported by Veblen et al. [49],
Villalba and Veblen [51] and Kitzberger et al. [24], who pointed out that cypress seedling establishment in xeric sites is greatly influenced by environmental conditions. In general and for both sites, it seems that after a fire event, the colonization of burned areas by pioneer herbs and shrubs could be a mechanism to avoid high temperatures extremes, that otherwise could overheat and dehydrate cypress seedlings. This protective effect against unfavourable microenvironmental conditions could prevail over that of competition, providing thus a safe site for successful establishment. In xeric sites, where cypress germination, growth and establishment is more sporadic and marginal, appropriate restoration practices could speed up successful post-fire establishment.

Acknowledgements: The authors wish to acknowledge Luciano Taladriz, Marcelo Rey, Ivor Roberts, Diego Truco, Cecilia Ciámpoli, Wessel de Meijere, Alejandro Martínez Meyer, Fernando Coronato and Mario Rajchenberg for their help in many stages of this study. This research was supported by the International Foundation for Science, Stockholm, Sweden (Grant No. D/3120/1), and by an assistantship from the Consejo Nacional de Investigaciones Científicas y Técnicas de Argentina (CONICET) to M. F. Urretavizcaya.

\section{REFERENCES}

[1] Agee J.K., Fire Ecology on Pacific Northwest, Island Press, Washington, D.C., 1993.

[2] Ahlgren C.E., Effects of fires on temperate forest: North Central United States, in: Kozlowski T., Ahlgren C.E. (Eds.), Fire and Ecosystems, Academic Press, New York, 1974, pp. 195-224.

[3] Albuinés M.R., Relevamiento y estudio del régimen climático de la provincia del Chubut, Informe de plan de trabajo $\mathrm{N}^{\circ} 1020$, INTA EEA Trelew, Chubut, Argentina, 1998.

[4] Awada T., Henebry G.M., Redmann R.E., Sulistiyowati H., Picea glauca dynamics and spatial pattern of seedlings regeneration along a chronosequence in the mixedwood section of the boreal forest, Ann. For. Sci. 61 (2004) 789-794.

[5] Bock C., Bock J., Shrub densities in relation to fire, livestock grazing, and precipitation in Arizona desert grassland, Southwest Nat. 42 (1997) 188-193.

[6] Bran D., Pérez A., Barrios D., Pastorino M., Ayesa J., Eco-región valdiviana: distribución actual de los bosques de "ciprés de la cordillera" (Austrocedrus chilensis) - Escala 1:250.000, INTA-APNFVSA, Bariloche, Argentina, 2002.

[7] Bustos J.C., Rocchi V.C., Caracterización termopluviométrica de veinte estaciones meteorológicas de Río Negro y Neuquén, Informe Técnico INTA EEA Bariloche, Río Negro, Argentina, 1993.

[8] Collmet Dâage F., Lanciotti M.L., Marcolin A.A., Importancia forestal de los suelos volcánicos de la Patagonia Norte y Central: Climo-topo-secuencia de suelos y vegetación, INTA EEA Bariloche, Argentina, 1995.

[9] Collmet Dâage F., Mazzarino M.J., Lanciotti A.A., Características de los suelos volcánicos en el S.O. del Chubut, Comunicación Técnica $\mathrm{N}^{\circ}$ 22, Recursos Naturales-Suelos, INTA EEA Bariloche, Argentina, 1993.

[10] De Fina A.L., El clima de la región de los bosques Andino-Patagónicos Argentinos, in: Dimitri M.J. (Ed.), La Región de los Bosques Andino-Patagónicos Sinopsis General, Colección Científica del INTA, Buenos Aires, Argentina, 1972, pp. 35-58.

[11] DeBano L.F., The effect of fire on soil properties. Symposium on Management and Productivity of Western-Montane Forest Soil, Boise, ID, April 10-12, 1990.

[12] DeBano L.F., The role of fire and soil heating on water repellency in wildland environments: a review, J. Hydrol. 231-232 (2000) 195-206. 
[13] DGByP, Estadísticas de incendios y análisis de causas, Informe Técnico Dirección General de Bosques y Parques de la Provincia del Chubut, Argentina, 1999.

[14] Gobbi M., Condiciones para la regeneración natural del ciprés de la cordillera (Austrocedrus chilensis) en áreas incendiadas, II Congreso Latinoamericano de Ecología, Brasil, 1992.

[15] Gobbi M., Regeneración de la vegetación en incendios recientes de bosques de "ciprés de la cordillera" (Austrocedrus chilensis) en el área del Parque Nacional Nahuel Huapi, Medio Ambiente 12 (1994) 9-15.

[16] Gobbi M., Austrocedrus chilensis management: effects on microsites and regeneration, Int. J. Ecol. Environ. Sci. 25 (1999) 71-83.

[17] Gobbi M., Sancholuz L., Regeneración post-incendio del "ciprés de la cordillera" (Austrocedrus chilensis) en los primeros años, Bosque 13 (1992) 25-32.

[18] Harper J.L., Population Biology of Plants, Academic Press, London, 1977.

[19] Iverson L.R., Hutchinson T.F., Soil temperature and moisture fluctuations during and after prescribed fire in mixed-oak forest, USA, Natural Areas J. 22 (2002) 296-304.

[20] Iverson L.R., Prasad A.M., Hutchinson T.D., Rebbeck J., Yaussy D.A., Fire and thinning in an Ohio oak forest: grid-based analyses of fire behavior, environmental conditions, and tree regeneration across a topographic moisture gradient, in: Spetich M.A. (Ed.), Upland oak ecology symposium: history, current conditions, and sustainability, Gen. Tech. Rep. SRS-73, Asheville, NC, USDA, Forest Service, SRS, 2004.

[21] Kimmins J.P., Forest Ecology: A Foundation for Sustainable Management, Prentice Hall, Upper Saddle River, New Jersey, 1997.

[22] Kitzberger T., Fire regime variation along a northern Patagonian forest-steppe-ecotone: stand and landscape response, $\mathrm{Ph} . \mathrm{D}$. thesis, Department of Geography, University of Colorado, Boulder, Colorado, 1994.

[23] Kitzberger T., Veblen T.T., Fire-induced changes in northern Patagonian landscapes, Landscape Ecol. 14 (1999) 1-15.

[24] Kitzberger T., Steinaker D.F., Veblen T.T., Effects of climatic variability on facilitation of tree establishment in northern Patagonia, Ecol. 81 (2000) 1914-1924.

[25] Kolb P.F., Robberecht R., High temperature and drought stress effects on survival of Pinus ponderosa seedlings, Tree Physiol. 16 (1996) 665-672.

[26] Kozlowski T.T., Pallardy S.G., Acclimatation and adaptative responses of woody plants to environmental stresses, Bot. Rev. 68 (2002) 270-334.

[27] Kozlowski T.T., Kramer P.J., Pallardy S.G., The physiological ecology of woody plants, Academic Press, San Diego, 1991.

[28] La Manna L., Caracterización de los suelos bajo bosques de Austrocedrus chilensis a través de un gradiente climático y topográfico en Chubut, Argentina, Bosque 26 (2005) 137-153.

[29] LaMarche V.C., Holmes R.L., Dunwiddie P.W., Drew L.G., Treering chronologies of the Southern Hemisphere, Argentina, Chronology Series V, Laboratory of Tree-ring Research, University of Arizona, Tucson, 1979.

[30] Lemmon P.E., A spherical densiometer for estimating forest overstory density, For. Sci. 1 (1956) 314-320.

[31] Letourneau F.J., Andenmatten E., Schlichter T., Effect of climatic conditions and tree size on Austrocedrus chilensis-shrub interactions in northern Patagonia, For. Ecol. Manage. 191 (2004) 29-38.

[32] Levitt J., Responses of plants to environmental stresses, Academic Press, New York, 1980.

[33] Macadam A., Effects of prescribed fire on forest soils, BC Ministry of Forest Research Report 89001-PR, Victoria, 1989.

[34] McMichael B.L., Burke J.J., Soil temperature and root growth, HortScience 33 (1998) 947-951.
[35] Neary D.G., Klopatek C.C., DeBano L.F., Folliott P.F., Fire effects on belowground sustainability: a review and synthesis, For. Ecol. Manage. 122 (1999) 51-71.

[36] O’Neill K.P., Kasischke E.S., Richter D.D., Environmental controls on soil $\mathrm{CO}_{2}$ flux following fire in black spruce, white spruce, and aspen stands of interior Alaska, Can. J. For. Res. 32 (2002) $1525-1541$.

[37] Pickett S.T.A., White P.S., The ecology of natural disturbance and patch dynamics, Academic Press, San Diego, 1985.

[38] PNMF, Plan Nacional de Manejo del Fuego, Estadísticas de incendios forestales de la Patagonia, Temporada 2001-2002, Secretaría de Ambiente y Desarrollo Sustentable, Buenos Aires, 2002.

[39] Pausas J.G., Ouadah A., Ferran A., Gimeno T., Vallejo R., Fire severity and seedling establishment in Pinus halepensis woodlands, eastern Iberian Peninsula, Plant Ecol. 169 (2003) 205-213.

[40] Pregitzer K.S., King J.S., Burton A.J., Brown S.E., Responses of tree roots to temperature, New Phytol. 147 (2000) 105-115.

[41] Pritchett W.L., Suelos forestales: propiedades, conservación y mejoramiento, Ed. Limusa, México, 1986.

[42] Robberecht R., Defossé G.E., The relative sensitivity of two bunchgrass species to fire, Int. J. Wildl. Fire 5 (1995) 127-134.

[43] Robberecht R., Bunting S.C., Defossé G.E., Response of bunchgrasses to fire: instrumentation and plant sensitivity, in: Proceedings of the 40th. annual Meeting of Society for Range Management, Boise, Idaho, 1987.

[44] Rovere A., Condiciones ambientales de la regeneración del ciprés de la cordillera (Austrocedrus chilensis), Bosque 21 (2000) 57-64.

[45] SAS Institute Inc. Manual of Software Version 8 (TS MO), Cary, NC, USA, 1999.

[46] SDSyPA, Series estadísticas forestales 1993-1999, Secretaría de Desarrollo Sustentable y Política Ambiental Dirección de Recursos Forestales Nativos, Departamento de Estadística Forestal, Buenos Aires, 2000.

[47] Urretavizcaya M.F., Defossé G.E., Soil seed bank of Austrocedrus chilensis (D. Don) Pic. Serm. et Bizzarri related to different degrees of fire disturbance in two sites of southern Patagonia, Argentina, For. Ecol. Manage. 187 (2004) 361-372.

[48] Veblen T.T., Kitzberger T., Villalba R., Donnegan J., Fire history in northern Patagonia: the roles of humans and climatic variation, Ecol. Monogr. 69 (1999) 47-67.

[49] Veblen T.T., Burns B., Kitzberger T., Lara A., Villalba R., The ecology of the conifers of Southern South America, in: Enright N., Hill R. (Eds.), Ecology of the Southern Conifers, Melbourne University Press, Carlton, Victoria, Australia, 1995, pp. 120-142.

[50] Villalba R., Climatic influences on forest dynamics along the forest-steppe ecotone in northern Patagonia, Ph.D. thesis, Department of Geography, University of Colorado, Boulder, Colorado, 1995.

[51] Villalba R., Veblen T.T., Regional patterns of tree population age structures in northern Patagonia: climatic and disturbance influences, J. Ecol. 85 (1997) 113-124.

[52] Viro P.J., Effects of forest fire on soil, in: Kozlowski T., Ahlgren C.E. (Eds.), Fire and Ecosystems, Academic Press, New York, 1974, pp. 7-46.

[53] Von Ende C.N., Repeated-measures analysis: growth and other time-dependent measures, in: Scheiner S.M., Gurevitch J. (Eds.), Design and analysis of ecological experiments, Chapman \& Hall, New York, 1993, pp. 113-137.

[54] Wild A., Condiciones de suelo y desarrollo de las plantas según Russell, Ed. Multi-Prensa, Madrid, 1992.

[55] Wong T.L., Harris R.W., Fissell R.E., Influence of high soil temperatures on five woody-plant species, J. Am. Soc. Hort. Sci. 96 (1971) 80-83.

[56] Wrigth H.A., Bailey A.W., Fire ecology, United States and Southern Canada, John Wiley \& Sons, USA, 1982. 